Agro-Science Journal of Tropical Agriculture, Food, Environment and Extension Volume 9 Number 3 September 2010 pp. $184-192$

ISSN 1119-7455

\title{
EFFECT OF SPROUTING AND PREGELATINIZATION ON THE COMPOSITION AND SENSORY PROPERTIES OF FLAKED BREAKFAST CEREAL PRODUCED FROM SORGHUM-PIGEON PEA BLENDS
}

\author{
Mbaeyi, I.E and Onweluzo, J.C. \\ Department of Food Science and Technology, University of Nigeria, Nsukka, Nigeria
}

\begin{abstract}
Sprouted (96-hour) and pregelatinized $\left(78^{\circ} \mathrm{C}\right)$ sorghum grains were milled and blended with graded proportions of pigeon pea (100:0, 80:20; 70:30; 60:40; 50:50) and used to formulate flaked breakfast cereal. A commercial ready-to-serve breakfast cereal served as product control. The composite flour blends and the formulated ready-to-serve breakfast cereals were analyzed for selected mineral composition and sensory quality. Results showed significant increase $(p \leq 0.05)$ in phosphorus, sodium and potassium content of sprouted samples and a decrease of calcium in the pregelatinzed samples. The presence of $20 \%$ level of pigeon pea flour improved some sensory attributes(colour, consistency flavour, mouth-feel, texture and overall acceptability) of the pregelatinized product and had a significant increase $(p<0.05)$ in comparison with the corresponding commercial product. Both sprouting and pregelatinization treatments, improved the composition of the breakfast cereal unlike their unblended/untreated counterparts.
\end{abstract}

Key words: Sprouting, pregelatinization, breakfast cereals, micronutrient deficiencies, sorghum, pigeon pea

\section{INTRODUCTION}

Over two billion people worldwide suffer from micronutrient malnutrition, often called "hidden hunger" (FAO, 2002). Micronutrient deficiency is a major public health problem with especially women and children being most vulnerable. The vulnerability of women stems from their higher need for micronutrients especially during pregnancies and child bearing years. Micronutrient deficiency usually occur when the habitual diet lacks diversity and do not include sufficient quantities of the good sources of micronutrients. These micronutrients are very essential for human growth and development as well as normal physiological functioning. Children and women are most vulnerable to these deficiencies, because of the critical importance of micronutrients for normal growth and development.

Three main strategies used in reducing micronutrient deficiencies, include dietary diversi-fication, fortification and diversification with supplements (Blum, 1999; Nnanyelugo, 1999). Dietary supplementation refers to an effective means of solving problems of micronutrient deficiency particularly in emergency situations to save lives due to mega-doses of micronutrient given at different age levels. it is a short time framed project where capsules or liquid food supplements are distributed to the target population (Nnanyelugo, 1996). Fortification of food refers to the addition of essential micronutrients to food particularly added to correct specific nutritional deficiencies such as addition of vitamins and iron to breakfast foods (cereals and beverages), fortification of sugar with vitamin A and fortification of table salt with iodine (Blum, 1997).

Dietary diversification involves the use of commonly available cereals, legumes and other nutritious crop to meet nutritional /dietary need of the population. It could be used to eliminate micronutrients deficiencies by modifying the diet to include a greater diversity of nutrient rich foods. Examples are complementary/weaning foods, convenient snacks, breakfast cereals among others. Meanwhile, the quality of the human foods could depend largely on the plant/animal materials used as the basic ingredients for the availability of micronutrients.

Micronutrient deficiency disease could result from seasonality of food or presence of antinutrient. Although the absolute level of micronutrients (especially minerals) in food might be sufficient, their bioavailability may 
be restricted due to the presence of some inherent anti-nutritional compounds such as phytate, tannins and cyanide among others. However, appropriate processing techniques could be employed to eliminate or reduce the anti-nutrients to safe levels and improve the bioavailability of the micro-nutrients. Such technique include flaking, gun puffing, pregelatinization, sprouting and extrusion cooking (Kent, 1983; Matz, 1993; Clark, 2006).

Food processing has inevitable consequences on the nutritional value of foods. The macro- and micronutrients(carbohydrates, protein, fats, vitamins, and minerals) contained within foods all show varying degrees of stability when foods are stored or processed (Henry and Massey, 2001). The degree of stability depends largely on the type and structure of the food/nutrient, food chemistry and duration of processing. A knowledge of the various food processes and the nutrient losses that occur during each process will allow improvements to be made and losses to be minimized.

Extrusion is widely used to restructure starch and protein-based materials to manufacture a variety of texture convenience foods. Upon heating and working during the extrusion process, the macromolecules in the food ingredients lose their native organized structure and form a continuous viscous dough(Enwere, 1998). The laminar flow within the channel on the extrusion screw and die align the large molecules in the direction of flow, exposing bonding sites which lead to cross-linking. Thus, a reformed, expandable structure that creates a crunchy or chewy texture in fabricated foods results. These products differ from convectional foods in that their basic components- proteins, fats and carbohydratesmay be derived from many sources and combined along with necessary micronutrients, flavours and colours, to form attractive products. Technological innovations have made it possible to obtain diverse raw materials and put them together in novel ways(Stanley, 1986).

Sprouting is a natural process in which dormant but viable seeds are induced to start growing into seedlings. Hormones are produced and enzymes are mobilized to convert stored foods such as insoluble carbohydrates and proteins to soluble components. Carbohydrates are converted to soluble sugars such as maltose and glucose by the various enzymes. Alpha-and betaamylases convert starch into glucose and maltose which are utilized by the germinating seeds. Sprouting is known to increase the vitamin $\mathrm{C}$ and mineral contents of seeds and impart a desirable flavor to an extruded product(Chavan and Kadam, 1989; Enwere,1998). Moreover, it has been shown to reduce the levels of phytates, tannins and oxalates in cereals. Vitamin $\mathrm{C}$ and riboflavin are synthesized during sprouting/germination therefore legumes are often germinated until they sprout (Henry and Massey, 2001).

Flaking is a relatively simple process of cooking fragments of cereal grains (or in some cases, whole grains) with water, flattening the particles between large steel rollers and toasting the resultant flake at high temperature (Matz, 1993). In flaking the starch in gelatinized and probably slightly hydrolyzed. The particle then undergoes dextrinization and caramelization (Kent, 1983). Cereals provide about three-quarters of both the energy and proteins intake of the world's population. All cereals require some form of processing prior to consumption, thereby introducing potential sources of nutrient loss. Cereals like wheat, oat, maize, barley and rice have been used in flaking. However, there are other grains that can be used but are presently unexploited. The use of all these cereals had been over-flogged while the ban on the importation of wheat in Nigeria has led to the search for good alternative from the lesser known or underutilized cereals such as sorghum, millet and "hungry" rice.

Sorghum (Sorghum bicolor L) is grown in large quantities in Nigeria. It is rich in some essential amino acid but low in lysine. Its main use is in local dishes in the tropics. To diversify the use of sorghum as a cereal and improve its protein and micronutrient level, sorghum could be supplemented with legumes such as Bambara groundnut, African yam bean, African breadfruit and pigeon pea among other legumes. Such supplementation have been used in products like weaning food (sorghum/pigeon-pea blends (Maghoub, 1999) and biscuit made with millet/pigeon-pea blends(Eneche, 1999). Pigeon pea (Cajanus cajan) is underutilized and contains relatively high amount of the amino acid lysine and therefore makes a good complement with sorghum.

Lastly, an increasing proportion of the household food budget in Nigeria is spent on indigenous processed foods like snack foods and breakfast cereals, of which convenience (on the part of the career women) and quality, are perceived as most important (Lasekan and Akintola, 2004). Also, there is an increase in urbanization in Nigeria. This paradigm shift 
has created changes in food habits and tastes. Many people have adjusted their tastes in preferences for convenience foods especially for breakfast (Echendu et al.,2004). Such flavourful and convenience foods include the flaked breakfast cereal. Thus, this study was therefore designed to evaluate the performance of sprouted and pregelatinized sorghum pigeon-pea composite for the production of nutritious flaked breakfast cereal.

\section{MATERIALS AND METHODS}

\section{Samples Procurement and Preparation}

Sorghum seeds (Sorghum bicolor L.) and pigeon pea (Cajanus cajan) were purchased from Ogige main market, Nsukka town, Enugu State, Nigeria. White variety $(1 \mathrm{~kg})$ of sorghum samples were preprocessed as described by Mbaeyi and Onweluzo, (2002). The samples were cleaned (to remove extraneous materials), sorted into different groups based on sizes, steeped (for 22hour wet-steep, 4hour air rest, 22 hour wet-steep at $28^{0} \mathrm{C} \pm 2^{0} \mathrm{C}$ for the grains to imbibe water (EtokAkpan and Palmer, 1990) and sprouted for 5 days. The sprouts were dried at $55^{\circ} \mathrm{C}$ for 20 hour in a hot air oven in order to remove moisture from the sprouted grains. After kilning of the sprouted grains at $85^{\circ} \mathrm{C}$ for 4 hour, the rootlets and cleoptile were devegetated. The devegetated grains were dry-milled using a hammer mill (Thomas Wiley mill, model Ed-5), sieved using a $1 \mathrm{~mm}$ pore-sized sieve and designated as sprouted sorghum flour (SSF).

A second batch of sorghum grains was cleaned, sorted, milled into flour and tagged untreated sorghum flour (USF). The grains were cleaned/sorted to remove extraneous materials, cracked to produce grits, conditioned, moistened and steamed at $100^{\circ} \mathrm{C} \pm 2^{\circ} \mathrm{C}$ for 10 minutes to pregelatinize the grits according to Pomeranz, (1985), and subsequently dried to a constant weight in hot air oven at $55^{\circ} \mathrm{C}$. The dried grits were drymilled using a hammer mill and the resultant flour was designated pregelatinized sorghum flour (PSF).

Pigeon pea (brown variety) was cleaned, sorted, graded into sizes, oil-treated for easy dehulling (Singh, 1995). The samples were dehulled, dried, dry-milled using a hammer mill (Thomas Wiley Mill model ED-5), sieved ( $1 \mathrm{~mm}$ pore sized sieve) and stored in air-tight polythene bag. It was designated as Cajanus cajan flour (CCF) and kept until used for product formulation and analysis.

Graded proportions of the differently treated flours were mixed to produce composite flour blends (sorghum:pigeonpea) used for product formulation of sorghum:pigeon pea in ratios of 100:0, 80:20; 70:30; 60:40; and 50:50. The blends were thoroughly mixed, slurried with sweetener and salt, baked in an oven, cooled and packaged in a high density polyethylene bag to maintain crispiness designated as flaked breakfast cereals as described by Mbaeyi(2005). The flour and their composites were conditioned and steamed for 10 minutes. The samples were divided into two portions. One portion was sweetened with sucrose while the other portion was salted using table salt $(\mathrm{NaCl})$. The steamed product was allowed to age at $4^{0} \mathrm{C}$ for 24 hours, cut, flaked and toasted in an oven at $150^{\circ} \mathrm{C}$ for one minute, cooled and packaged in a highdensity polythene bag to maintain crispness.

\section{Mineral Content Determination}

The mineral content of the flour and their composites were evaluated using the method described by Adedeye and Adewoke (1992). One gram of dried samples were digested with $2.5 \mathrm{ml}$ of $0.03 \mathrm{~N}$ hydrochloric acid $(\mathrm{HCl})$. The digest was boiled for 5 minutes, allowed to cool to room temperature and transferred to $50 \mathrm{ml}$ volumetric flakes and made up to the mark with diluted water. The resulting digest was filtered with ashless Whatman No. 1 filter paper. Filtrates from each sample was analyzed for mineral (calcium, sodium, potassium and phosphorus) contents using an Atomic Absorption Spectrophotometer (Buck Scientific Atomic Absorption Emission Spectrophotometer model 200-A, 1992, manufactured by Nowalk, Connecticut, USA). The wavelengths of absorption for the different elements were $422.70 \mathrm{~nm}$ (for calcium) $589.0 \mathrm{~nm}$ (for sodium), $766.50 \mathrm{~nm}$ (for potassium) and 470.00nm (for phosphorus). The real values were extrapolated from the respective standard curves. Values obtained were adjusted for $\mathrm{HCl}$-extractability for the respective ions. All determinations were performed in triplicates. 


\section{Sensory evaluation}

The consumer preference test was performed on the products by ranking flaked samples as described by Meilgaard, et al.(1991).A panel of 20 judges ranked the products on 9-point Hedonic scale (9 representing the highest degree of likeness and 1 representing the least degree of dislikeness). A commercial product (cornflakes by NASCO, Jos) served as control. Thirty-two flaked products were ranked on the basis of the intensity of some selected characteristics such as aftertaste colour, crispiness and texture. Based on the results of ranking, preferred products were selected.

The best-ranked products were subjected to further evaluation using 20 panelists. The products were scored for colour, consistency, flavour, texture, mouthfeel, and aftertaste, sweetness and overall acceptability on a 9-point Hedonic scale, a commercial product, cornflakes (NASCO, Jos) served as the control. The products were prepared (with hot or cold milk, sugar or honey). The order of presentation to the panel members was randomized.

\section{Data Analysis}

Sensory scores were subjected to Analysis of Variance (ANOVA) and mean separation was by Snedecor and Cochran, (1980). The Least Significant Difference (L.S.D) value was used to determine significant differences between means and to separate means at $\mathrm{p} \leq 0.05$ using SPSS package version 15.0 .

\section{RESULTS AND DISCUSSION \\ Effect of Sprouting and Pregelatinization on Mineral Content}

The data for the effect of sprouting and pre-gelatinization on micronutrient content of the samples is presented in Table 1. The Calcium (Ca) content ranged from 137.05 to $156.34 \mathrm{mg} / 100 \mathrm{~g}$ in pregelatinized and 137.41 to $156.96 \mathrm{mg} / 100 \mathrm{~g}$ in the sprouted composite flours respectively. The untreated sample had a calcium content of between 137.50 to $165.18 \mathrm{mg} / 100 \mathrm{~g}$. The pregelatinized flour blend $(80: 20)$ had the lowest calcium value of $137.05 \mathrm{mg} / 100 \mathrm{~g}$ while CCF (100:0) had the highest $(174.55 \mathrm{mg} / 100 \mathrm{~g})$ value. The calcium content within the stated ranges was attributed to sorghum and pigeon pea being good dietary sources of minerals. Samples containing sprouted sorghum flour showed more percentage calcium than those containing pregelatinized flour. Other researchers (Obizoba and Atii, 1994) reported decrease in calcium, potassium and magnesium due to the leaching of mineral into the medium (water). Samples containing sprouted sorghum flour showed more calcium than those containing pregelatinized blends. An increase of about $10 \mathrm{mg} / 100 \mathrm{~g}$ observed in the calcium content of the sprouted sorghum flour may be probably due to complexes of calcium with phytate found in the husk of sorghum (FAO/WHO, 2002). Obizoba and Atii(1994) noted that during sprouting the activities of hydrolytic enzymes may lead to the release of more free calcium from its organic complexes. Similar observations were made by Van De Riet, et al. (1987) in germinated legumes seeds

Table 1: Mineral Content of Sprouted and Pregelatinized Sorghum and Pigeon Pea Flours and their Blends

\begin{tabular}{|c|c|c|c|c|}
\hline \multirow[b]{2}{*}{ Sample } & \multicolumn{4}{|c|}{ Mineral contents (mg/100g) } \\
\hline & $\mathbf{C a}$ & $\mathbf{K}$ & $\mathbf{N a}$ & $\mathbf{P}$ \\
\hline $\mathrm{USF}+\mathrm{CCF}(100: 0)$ & 137.50 & 104.0 & 138.0 & 215.30 \\
\hline $\mathrm{USF}+\mathrm{CCF}(80: 20)$ & 146.86 & 166.0 & 187.3 & 669.4 \\
\hline $\mathrm{USF}+\mathrm{CCF}(70: 30)$ & 152.05 & 248.0 & 173.4 & 618.8 \\
\hline $\mathrm{USF}+\mathrm{CCF}(60: 40)$ & 165.18 & 419.0 & 151.9 & 959.9 \\
\hline $\mathrm{USF}+\mathrm{CCF}(50: 50)$ & 156.61 & 310.0 & 184.9 & 829.4 \\
\hline PSF+CCF (100:0) & 140.09 & 107.0 & 145.6 & 554.1 \\
\hline $\mathrm{PSF}+\mathrm{CCF}(80: 20)$ & 137.05 & 122.0 & 184.8 & 505.9 \\
\hline $\mathrm{PSF}+\mathrm{CCF}(70: 30)$ & 56.00 & 263.0 & 167.1 & 768.2 \\
\hline $\mathrm{PSF}+\mathrm{CCF}(60: 40)$ & 150.54 & 258.0 & 170.9 & 687.0 \\
\hline $\mathrm{PSF}+\mathrm{CCF}(50: 50)$ & 156.34 & 328.0 & 158.2 & 764.7 \\
\hline $\mathrm{SSF}+\mathrm{CCF}(100: 0)$ & 137.41 & 199.0 & 97.5 & 349.4 \\
\hline $\mathrm{SSF}+\mathrm{CCF}(80: 20)$ & 154.33 & 270.0 & 141.8 & 683.5 \\
\hline $\mathrm{SSF}+\mathrm{CCF}(70: 30)$ & 156.16 & 241.0 & 158.2 & 751.8 \\
\hline $\mathrm{SSF}+\mathrm{CCF}(60: 40)$ & 156.96 & 280.0 & 165.8 & 820.0 \\
\hline $\mathrm{SSF}+\mathrm{CCF}(50: 50)$ & 155.36 & 350.0 & 141.7 & 788.2 \\
\hline CCF (100:0) & 174.55 & 660.0 & 164.6 & 108.1 \\
\hline
\end{tabular}

Key: $\mathrm{Ca}=$ Calcium $; \mathrm{K}=$ Potassium; $\mathrm{Na}=$ Sodium; $\mathrm{P}=$ Phosphorus

$\mathrm{PSF}=$ Pregelatinized sorghum flour; $\mathrm{SSF}=$ Sprouted sorghum flour;

$\mathrm{CCF}=$ Cajanus cajan flour; $\quad$ USF $=$ Untreated sorghum flour 
The sodium $(\mathrm{Na})$ content ranged between 97.56 and $187.3 \mathrm{mg} / 100 \mathrm{~g}$. Sample $\mathrm{SSF}+\mathrm{CCF} \quad(100: 0)$ showed the least $(97.5 \mathrm{mg} / 100 \mathrm{~g})$ sodium content while sample USF+CCF (80:20) had the highest value of $187.3 \mathrm{mg} / 100 \mathrm{~g}$. Generally, the release of sodium was higher in the sprouted flours followed by the pregelatinized flours and then the untreated flours Sodium increased due to increase in sprouted samples added to the pregelatinized samples. Similar results were obtained by Obizoba and Amaechi (1992).

The phosphorus (P) content ranged from $108.12 \mathrm{mg} / 100 \mathrm{~g}$ in sample $\mathrm{CCF}(100: 0)$ to $959.9 \mathrm{mg} / 100 \mathrm{~g}$ in sample $\mathrm{USF}+\mathrm{CCF}$ (60:40). Sample CCF (100:0) had the least phosphorous level $(108.12 \mathrm{mg} / 100 \mathrm{~g})$ while sample USF+CCF $(60: 40)$ had the highest value $(959.9 \mathrm{mg} / 100 \mathrm{~g})$. Sprouting decreased phosphorus. This was attributed to possible reaction from phytin complex by phytase (a commonly observed phenomenon). The observed decrease in the phosphorous level of the treated flours could be as a result of the utilization of the nutrients for metabolism during sprouting and hence, the preference (Obizoba and Amaechi, 1992). The increase in blending ratio increased the mineral content. Supplementation of the sorghum flour with pigeon pea increased the calcium, potassium, phosphorus and sodium. Higher values of the minerals were observed in blends containing treated sorghum (sprouted and pregelatinized) sample than in the untreated samples. Many minerals form complexes with antinutritional factors thereby reducing their bioavailability. The increasing metabolic enzymes of sprouting release more minerals from their bound complexes with anti-nutrient (Obizoba and Egbuna, 1991; Nnam, 2000). Thus, sprouting increased the levels of the minerals in the treated samples.

\section{Effect of Sprouting and Pregelatinization on Consumers' Preference Test of Formulated Flaked Breakfast Cereal Products}

The randomized ranking of the formulated breakfast cereal products in Table 2 shows the consumer preference for sweetened products to the salted ones. The sweetened products had average mean values ranging between 4.91 and 19.58 while the salted samples ranged between 10.72 and 27.25. The implication is that the consumers preferred the sweetened samples. These sweetened products were compared with the commercial product (NASCO cornflakes). Also, the pregelatinized sweetened sample$\mathrm{PSF}+\mathrm{CCF}(60: 40)$ was most preferred probably due to the improved texture, taste, aroma and colour (Enwere, 1998).

Table 2: Ranking of Formulated Breakfast Cereals

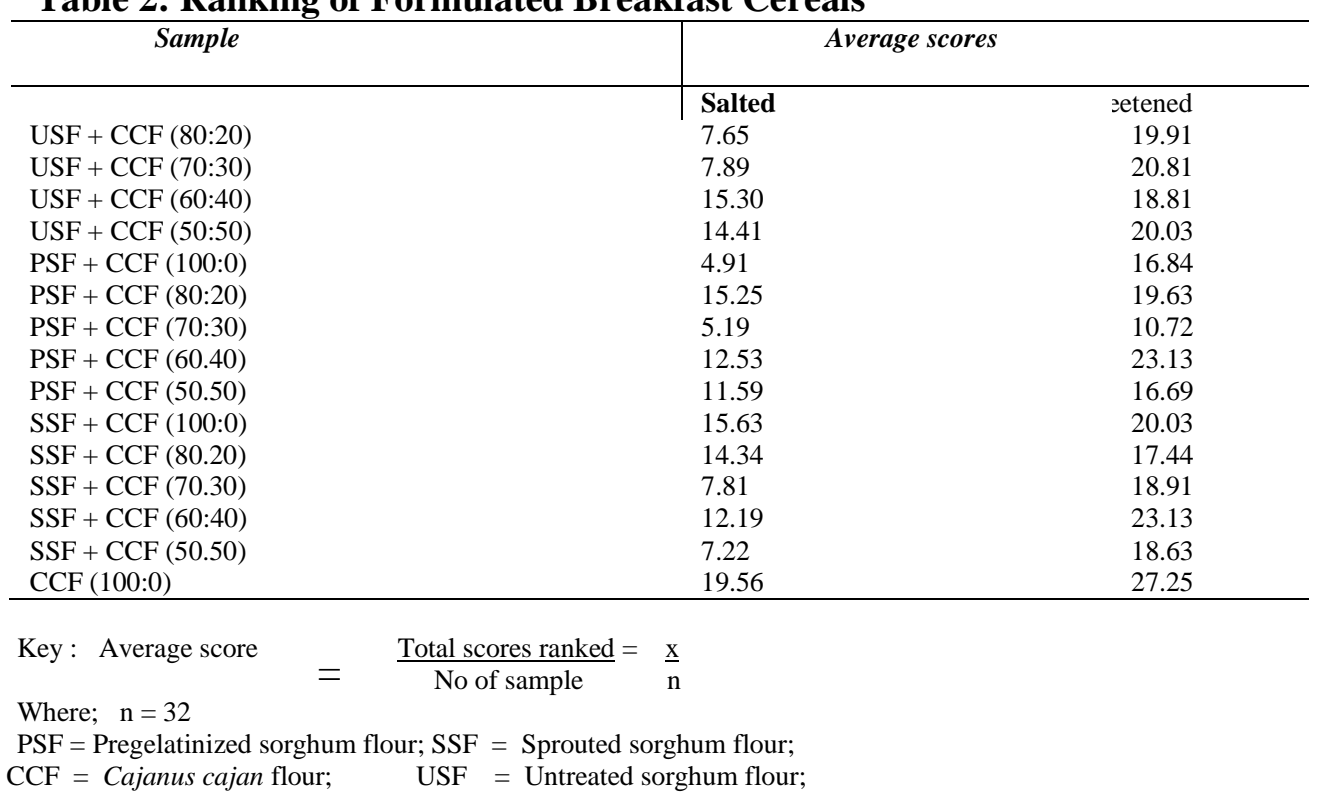


Composition and Sensory Properties of Flaked Breakfast Cereal

Table 3: Sensory Evaluation Scores of the Formulated Products and a Commercial Product (Content)

\begin{tabular}{|c|c|c|c|c|c|c|c|c|c|c|c|c|c|c|c|c|c|c|c|c|c|}
\hline \multirow[b]{2}{*}{ Attributes } & \multicolumn{21}{|c|}{ Sweetened samples } \\
\hline & A & B & $\mathbf{C}$ & D & $\mathbf{E}$ & $\mathbf{F}$ & G & $\mathbf{H}$ & I & $\mathbf{J}$ & $\mathbf{K}$ & $\mathbf{L}$ & $\mathbf{M}$ & $\mathbf{N}$ & $O$ & $\mathbf{P}$ & $\mathbf{Q}$ & $\mathbf{R}$ & $\mathbf{S}$ & $\mathbf{T}$ & L.SD \\
\hline Acceptability & $7.5^{\mathrm{a}}$ & $6.8^{\mathrm{ab}}$ & $6.1^{\text {bcd }}$ & $6.3^{\mathrm{bcd}}$ & $5.9^{\mathrm{cd}}$ & $6.5^{\text {abcd }}$ & $6.5^{\text {abcd }}$ & $6.5^{\text {abcd }}$ & $6.5^{\text {abcd }}$ & $6.6^{\text {abcd }}$ & $5.8^{\mathrm{cd}}$ & $6.8^{\mathrm{abc}}$ & $6.2^{\text {bcd }}$ & $7.1^{\mathrm{ab}}$ & $6.5^{\text {abcd }}$ & $5.7^{\mathrm{d}}$ & $6.3^{\text {abcd }}$ & $6.5^{\text {abcd }}$ & $6.5^{\text {abcd }}$ & $8.6^{\mathrm{a}}$ & 1.03 \\
\hline After-taste & $7.0^{\mathrm{a}}$ & $6.7^{\mathrm{ab}}$ & $5.9^{\text {bcd }}$ & $5.3^{\text {cd }}$ & $5.2^{\mathrm{cd}}$ & $6.0^{\mathrm{abcd}}$ & $6.0^{\text {abcd }}$ & $6.0^{\mathrm{abcd}}$ & $5.1^{\mathrm{d}}$ & $6.5^{\mathrm{ab}}$ & $6.3^{\mathrm{cd}}$ & $6.0^{\mathrm{abcd}}$ & $5.0^{\mathrm{d}}$ & $6.2^{\mathrm{abc}}$ & $6.1^{\text {abcd }}$ & $5.4^{\mathrm{cd}}$ & $5.2^{\mathrm{bcd}}$ & $5.8^{\mathrm{bcd}}$ & $5.9^{\mathrm{bcd}}$ & $8.5^{\mathrm{a}}$ & 1.09 \\
\hline Colour & $6.6^{\mathrm{a}}$ & $5.7^{\mathrm{ab}}$ & $5.4^{\mathrm{bcd}}$ & $6.5^{\mathrm{a}}$ & $5.0^{\text {bcde }}$ & $4.3^{\text {def }}$ & $4.8^{\text {bcde }}$ & $5.0^{\text {bcde }}$ & $5.6^{\mathrm{abc}}$ & $4.5^{\mathrm{def}}$ & $4.1^{\mathrm{ef}}$ & $5.4^{\mathrm{bcd}}$ & $5.7^{\mathrm{ab}}$ & $5.4^{\mathrm{bcd}}$ & $2.6^{\mathrm{f}}$ & $4.7^{\text {cde }}$ & $3.6^{\mathrm{bcd}}$ & $5.3^{\mathrm{bcd}}$ & $4.3^{\mathrm{ef}}$ & $8.4^{\mathrm{a}}$ & 0.96 \\
\hline Consistency & $7.3^{\mathrm{a}}$ & $6.4^{\mathrm{ab}}$ & $7.0^{\mathrm{ab}}$ & $6.7^{\mathrm{ab}}$ & $6.2^{\mathrm{b}}$ & $5.9^{\mathrm{bc}}$ & $6.5^{\mathrm{ab}}$ & $6.3^{\mathrm{ab}}$ & $7.0^{\mathrm{ab}}$ & $6.7^{\mathrm{ab}}$ & $6.3^{\mathrm{ab}}$ & $6.4^{\mathrm{ab}}$ & $6.9^{\mathrm{ab}}$ & $6.7^{\mathrm{ab}}$ & $6.4^{\mathrm{ab}}$ & $6.0^{\mathrm{ab}}$ & $6.3^{\mathrm{ab}}$ & $6.3^{\mathrm{ab}}$ & $6.0^{\mathrm{b}}$ & $8.9^{\mathrm{a}}$ & 1.04 \\
\hline Flavour & $7.2^{\mathrm{a}}$ & $6.7^{\mathrm{ab}}$ & $6.0^{\mathrm{bc}}$ & $6.1^{\mathrm{bc}}$ & $5.4^{\mathrm{c}}$ & $6.0^{\mathrm{cd}}$ & $6.3^{\mathrm{abc}}$ & $6.2^{\mathrm{abc}}$ & $6.3^{\mathrm{abc}}$ & $6.7^{\mathrm{ab}}$ & $6.2^{\mathrm{ab}}$ & $6.5 \mathrm{bc}$ & $5.9^{\mathrm{bc}}$ & $6.5^{\mathrm{bc}}$ & $6.3^{\text {adc }}$ & $5.5^{\mathrm{c}}$ & $6.7^{\mathrm{ab}}$ & $6.8^{\mathrm{a}}$ & $6.3^{\mathrm{abc}}$ & $8.7^{\mathrm{a}}$ & 0.96 \\
\hline Mouth-feel & $5.9^{\mathrm{a}}$ & $5.8^{\mathrm{abc}}$ & $5.2^{\mathrm{abcd}}$ & $4.8^{\mathrm{d}}$ & $5.0^{\mathrm{bcd}}$ & $4.9^{\mathrm{cd}}$ & $5.3^{\mathrm{abcd}}$ & $4.7^{\mathrm{d}}$ & $4.9^{\text {cd }}$ & $6.3^{\mathrm{a}}$ & $4.5^{\mathrm{b}}$ & $4.7^{\mathrm{d}}$ & $4.5^{\mathrm{d}}$ & $5.5^{\mathrm{abcd}}$ & $6.1^{\mathrm{ab}}$ & $5.0^{\mathrm{cd}}$ & $5.0^{\mathrm{cd}}$ & $5.0^{\mathrm{cd}}$ & $5.9^{\mathrm{abc}}$ & $8.4^{\mathrm{a}}$ & 1.17 \\
\hline Sweetened & $7.1^{\mathrm{a}}$ & $6.4^{\mathrm{abc}}$ & $5.8^{\mathrm{c}}$ & $6.0^{\mathrm{abc}}$ & $6.4^{\mathrm{c}}$ & $6.4^{\mathrm{abc}}$ & $6.2^{\mathrm{abc}}$ & $5.7^{\mathrm{c}}$ & $6.0^{\mathrm{bc}}$ & $6.3^{\mathrm{abc}}$ & $5.3^{\mathrm{c}}$ & $6.3^{\mathrm{abc}}$ & $5.4^{\mathrm{c}}$ & $6.7^{\mathrm{abc}}$ & $6.4^{\mathrm{abc}}$ & $5.7^{\mathrm{c}}$ & $6.8^{\mathrm{ab}}$ & $5.7^{\mathrm{c}}$ & $6.5^{\mathrm{abc}}$ & $8.5^{\mathrm{a}}$ & 0.81 \\
\hline Texture & $6.5^{\mathrm{ab}}$ & $6.5^{\mathrm{ab}}$ & $6.2^{\mathrm{abc}}$ & $7.0^{\mathrm{a}}$ & $5.8^{\mathrm{b}}$ & $6.5^{\mathrm{b}}$ & $6.5^{\mathrm{ab}}$ & $6.0^{\mathrm{b}}$ & $6.5^{\mathrm{ab}}$ & $6.7^{\mathrm{ab}}$ & $6.0^{\mathrm{b}}$ & $6.3^{\mathrm{ab}}$ & $5.5^{\mathrm{b}}$ & $6.4^{\mathrm{ab}}$ & $6.0^{\mathrm{b}}$ & $5.5^{\mathrm{b}}$ & $5.9^{\mathrm{b}}$ & $5.9^{\mathrm{b}}$ & $5.9^{\mathrm{b}}$ & $8.4^{\mathrm{a}}$ & 0.93 \\
\hline
\end{tabular}

All value means of 20 panelists.

Values within rows of having same superscripts are significantly $(\mathrm{p}<0.05)$ different

PSF = Pregelatinized sorghum flour; $\quad$ SSF $=$ Sprouted sorghum flour; CCF = Cajanus cajan flour; USF= Untreated sorghum flour

$\mathrm{A}=\mathrm{PSF}+\mathrm{CCF}(100: 0) ; \mathrm{B}=\mathrm{USF}+\mathrm{CCF}(80: 20) ; \mathrm{C}=\mathrm{USF}(100: 0) ; \mathrm{D}=\operatorname{PSF}+\mathrm{CCF}(70: 30) ; \mathrm{E}=\mathrm{SSF}+\mathrm{CCF}(50: 50) ; \mathrm{F}=\mathrm{SSF}+\mathrm{CCF}(100: 0) \mathrm{G}=\mathrm{CCF}(100: 0)$

$\mathrm{H}=\mathrm{SSF}+\mathrm{CCF}(60: 40) ; \mathrm{I}=\mathrm{USF}+\mathrm{CCF}(60: 60) ; \mathrm{J}=\mathrm{USF}+\mathrm{CCF}(50: 50) ; \mathrm{K}=\mathrm{SSF}+\mathrm{CCF}(70: 30) ; \mathrm{L}=\mathrm{PSF}+\mathrm{CCF}(60: 40) ; \mathrm{M}=\mathrm{SSF}+\mathrm{CCF}(80: 20) ; \mathrm{N}=\mathrm{PSF}+\mathrm{CCF}(50: 50) ; \mathrm{O}=\mathrm{PSF}+\mathrm{CCF}(80: 20) ;$

$\mathrm{P}=\mathrm{USF}+\mathrm{CCF}(70: 30) ; \mathrm{Q}=\mathrm{USF} ; \mathrm{R}=\mathrm{PSF} ; \mathrm{S}=\mathrm{SSF} ; \mathrm{T}=$ control. 
Sensory quality of consumer preferred samples of Flaked Breakfast Cereals

Table 3 shows the sensory scores of the formulated products and a commercial product (NASCO Cornflakes) used as positive control.

Colour: Product A (PSF+CCF-100:0 pregelatinized sorghum flour without Cajanus cajan flour) showed the highest mean colour score (6.6) among the formulated products and the value differed significantly $(p \geq 0.05)$ from the control $(\mathrm{T})$ which showed a mean score of 8.5. Pregelatinization involved heating which led to the gelatinization of starch in the formulated samples and the interaction of the other ingredient in food. These changes altered the colour of the pregelatinized samples used for the flaked products. Furthermore, the heat treatment during baking increased the browning effect on the flaked products (Liener, 1985) unlike the sprouting which involved no heating.

Consistency: Product A(PSF+CCF -100:0) had the highest mean value (7.3) while product $\mathrm{F}$ (SSF+CCF -100:0 sprouted sorghum flour without Cajanus cajan flour) had the least value(5.9) which differed significantly $(\mathrm{p} \leq 0.05)$ from the control (8.9). Except sample F, other formulated products did not differ significantly ( $p>0.05$ ) from the control.

Flavour: Product A (PSF+CCF -100:0) showed the highest mean $\operatorname{score}(7.2)$ for flavour among the formulated product and the value did not differ significantly $(\mathrm{p}>0.05)$ from the control (T) which showed a mean value of 8.5. Dry heat treatment of the pre-gelatinized products may have released more flavour compounds in the pregelatinized product than in the sprouted product. The flavour of the pregelatinized products was enhanced probably due to the release of the flavour compounds (acetates) than the sprouted counter parts that was evident on tasting the flaked product. Although the pregelatinized products were preferred, the derived flavour of the sprouted products was imparted during the amylolytic conversion of starch (complex carbohydrates) to simple sugars (that is the enzymatic mobilization to convert the insoluble carbohydrates and proteins to soluble components). Similar reports were obtained by Osho and Adenekun, 1992).

Mouthfeel: Product A(PSF+CCF -100:0) had the highest mean value of 5.7 which did not differ $(\mathrm{p}>0.05)$ from the control $(\mathrm{T})$ with a mean score of 8.5. Pregelatinization improved the palatability of the product more than the sprouted product.

Sweetness: Product A(PSF+CCF -100:0) had the highest mean value of 7.1 and product $\mathrm{K}$ (SSF+ CCF -70:30 sprouted sorghum flour with Cajanus cajan flour) had the least mean value. Product A did not differ significantly $(\mathrm{p}>0.05)$ from the control $(\mathrm{T})$ having a mean value of 8.5. The panelists preferred the sweetened formulated products probably due to the natural likeness for the sweetener (sugar) (Obizoba and Atii, 1994).

Texture: Sample D - PSF+CCF -70:30] showed the highest mean score (7.0) for texture while sample $\mathrm{M}(\mathrm{SSF}+\mathrm{CCF}-80: 20)$ and $\mathrm{Q}=$ USF-untreated sorghum flour] had the least score (5.5) and the mean value of the cornflakes was 8.4. There was a slight difference between the texture of the formulated products and cornflakes. Supplementation influenced the texture of the products. The texture of the formulated products, though crispy, was hard unlike the NASCO cornflakes. The texture of the pregelatinized formulated products and the NASCO cornflakes were preferred. Between the treated composite blends, panelists preferred the texture of pregelatinized product(Product D) than the sprouted products probably because of the treatment.

Overall Acceptability: The overall acceptability of the products differed significantly $(\mathrm{p}<0.05)$ among the products. Product A(PSF +CCF -100:0) was most preferred by the panelists and so had the highest mean score of 7.5. The control had mean overall score of 8.6, which did not differ significantly from products. But significantly different $(\mathrm{p} \leq 0.05)$ from sample P. Among the formulated products, the products containing the pregelatinized sorghum were more preferred to those containing the sprouted sorghum probably due to the heat treatments which generally developed improved texture and flavour in the resulting products (Enwere, 1998). Thus, sprouting and pregelatinization, when controlled, led to a significant improvement in nutritive composition, flavour, texture and colour of the food product. The use of pregelatinized cereal-legume flour blends is not very common in Nigeria. Promotion will be required to popularize the use of pregelatinized composites or flour blends, which has some nutritional benefits over the sprouted products. 


\section{CONCLUSION}

From the results of the study, breakfast cereals convenient foods) could be formulated from graded proportions of preprocessed sorghum and pigeon-pea. The products from the sprouted and pregelatinized sorghum-pigeon pea composite flours were acceptable as they offer new uses of the staples when compared with their untreated counterparts. Their uses could be much more effective in children and adult feeding because of the increased protein and energy contents respectively (Mbaeyi, 2005).

It is apparent from the findings that pregelatinization and sprouting treatments improved the quality of the formulated breakfast cereal and flaking had a significant impact on the bioavailability of the minerals. The mineral contents(calcium, potassium, phosphorus and sodium) increased significantly $(\mathrm{p}<0.05)$. The consumers preferred the pregelatinized sweetened flaked breakfast cereal to the sprouted products with respect to colour consistency, flour, mouthful, sweetness and overall acceptability unlike the texture when compared with the commercial control. Thus, pregelatinization improved palatability of the flaked products.

Finally, both sprouting and pregelatinization methods appear to be promising processing techniques for preparing delicious cereal legume mix products (breakfast cereal) and in turn, extending the shelf life of the products. Also, the products could serve as a sole source of nutrients for children and supplements for adults. Sprouted and pregelatinized flour probably have much more nutrients and acceptance than the unblended/untreated counterpart. Pregelatinization and sprouting should be encouraged as part of routine processing of cereals and legumes.Thus, the blends of the sprouted and pregelatinized legume and cereal should be made a popular food in Nigeria and beyond through nutrition education.

\section{REFERENCES}

Adedeye, A and Adewoke, K. (1992). Chemical composition and fatty acid profiles of cereals in Nigeria. Food Chemistry, 44:41-44

Blum, M. (1997). Food fortification: A key strategy to end micronutrient malnutrition Nutriview, 97: 1-22.

Chavan, J.K.and Kadam, S.S.(2001). Nutritional improvement of cereals by sprouting. Critical Reviews on Food Science and Nutrition 28(5): 401-437.
Clark, J.P. (2006). Processing breakfast cereals to deliver nutrition. Food Technology, 3: 89-94

Echendu, C.A, Onimawo, I.A. and Somtochi, A. (2004). Production and evaluation of doughnuts biscuits from maizepigeon pea flour blends. Nigerian Food Journal, 22: 147-153.

Eneche, E.H (1990). Biscuit-making potential of millet/Pigeon-pea flour blends. Plant Foods for Human Nutrition, 54:21-27.

EtokApkan, O.U. and Palmer, G.H. (1990). Comparative studies on the development of Endosperm degrading enzymes in malting sorghum and barley. World. Journal of Microbial Biotechnology, 6: 408-417.

Enwere, N.J. (1998). Enhancing the Quality of Food through preservation and processing. In: Foods of Plant origin, Afro-orbis publications Ltd., Nsukka, Nigeria, pp 181-214.

FAO (2002). The state of food insecurity in the world. Food and Agriculture Organization, Italy, pp 24-25.

FAO/WHO (2002). Human vitamin and mineral requirement. Report of a Joint FAO/WHO Expert Consultation, Bangkok, Thailand, pp 151-18).

Henry, C.J.K. and Massey, D.(2001). Micronutrient changes during food processing and storage. Crops PostHarvest Programme (CPHP) - Issue Paper 5, December,2001).

Kent, N.L. (1983). Technology of cereal, Pergamon Press, Oxford pp 139-142

Lasekan, O.O and Akintola, A.M (2004). Production and nutritional evaluation of puffed soy maize snack. Nigerian Food Journal, 22: 15-19.

Maghoub, S.E.O. (1999). Production and evaluation of weaning foods based on Sorghum and legumes. Plant Foods for Human Nutrition 54: 29-42.

Matz, S.A. (1993). Breakfast cereals. In: The chemistry and technology of cereals as food and feed. AVI Publ. Co., Westport, Connecticut, pp 645-676.

Mbaeyi, I.E. (2005). Production and evaluation of breakfast cereal using pigeon-pea (Cajanus cajan) and sorghum (Sorghum bicolor L.) An M.Sc. Thesis Department of Food Science and Technology, University of Nigeria, Nsukka.

Mbaeyi, I.E. and Onweluzo, J.C. (2002). Effect of sprouting and pregelatinizaton on the Nutritional Quality of Sorghum (Sorghum bicolor L.). Proceedings of 
the $26^{\text {th }}$ Annual NIFST Conference, $4^{\text {th }}-8^{\text {th }}$ October 2003, Owerri.

Meilgaard, M; Cille, G.V. and Carr, B.T. (1991). Sensory evaluation technology, $2^{\text {nd }}$ ed; CRC Press Inc., Boca Raton, Florida, pp 22-45.

Nnam, N.M. (2000). Evaluation of the effect of sprouting on the viscosity, proximate composition and mineral content of Hungry rice, Acha (Digitaria exilis) flours. Nigerian Food Journal 18:5762.

Nnam, N.M. (2001). Chemical and rheological properties of porridges from processed sorghum (Sorghum bicolor L.), Bambara groundnut (Vigna subterranean $L$. verdc) and Sweet Potato (Ipomea bataas) flours. Plant Foods for Human Nutrition, 56: 251264

Nnanyelugo, D.O. (1999). Opportunities for food fortification technology in Nigeria. Vitamin Information Centre, South Africa, pp 1-17.

Obizoba, I.C. and Amaechi, W.A. (1992). The effect of processing methods of the chemical composition on baobab (Adeneseoma digitata L.) pulp and seed Ecol. Food Nutr. 45:23-34.

Obizoba, I.C. and Atii, V.J. (1994). Evaluation of the effect of processing technique on the nutrient and anti-nutrient of pear millet (Penniestum glacum) seeds. Plants Food Human Nutrition 45: 23-34.

Obizoba, I.C. and Egbuna, H.I. (1991). Effect of germination and fermentation on the nutritional quality of bambara nut (voandzeia subterranean L. Thouars) and its product milk. Plant Foods for human Nutrition 41:1-10.

Osho, S.M. and Adenekan, I.G. (1992). Production and Nutritional evaluation of soybean fortified malted sorghum meal extrudate. In: Second year Technical Report April 1, 1991 to April 30, 1992, Dec/IITA Soybean utilization Project phase II. S.M. Osho and K. E. Dashiel (eds) IITA, Ibadan, pp 155-174.

Pomeranz, Y. (1985). Functional properties of food components-carbohydrate starches, Academic Press. Inc. New York, pp 25-89.

Singh (1995). Methods of dehulling of pulsesA critical appraisal. Journal of Food Science and Technology 32 (2): 8193.

Snedecor, G.W. and Cochran, W.G. (1980). Statistical methods, $17^{\text {th }}$ Ed. The IOWA State Univ. Press, Ames. I.A; pp 155-170.

Stanley, D.W.(1986). Chemical and Structural determinants of texture of fabricated foods. Food Technology 41(3): 65- 68. 